\title{
UnoUnoptimized Protection of Migrant Workers in the Framework of ASEAN Regional Cooperation
}

\author{
Tirza Mariani Claudya \\ \{tirzamariani@gmail.com\} \\ Faculty of Law \\ Christian University of Indonesia \\ Mayjen Sutoyo No.2, RT.9/RW.6, Cawang, \\ Kramat Jati, Kota Jakarta Timur, Daerah Khusus Ibukota Jakarta 13630
}

\begin{abstract}
The purpose of this paper is to identified the unoptimizing the protection of migrant workers with synchronize ASEAN regional cooperation policy in the pandemic Covid-19 situation. The methodology of this paper used desk study approach. The results of this study show several policies to optimize the protection of migrant workers with the development of policies in the disclosure of information related to migrant care through center excellences ; the cluster that ASEAN countries should be able to provide assurance access of health protection related to Pandemic Covid-19 against all migrant workers in ASEAN countries by conducting rapid tests ; as well as migrant workers are reserved health protections are equal with ASEAN Society. The suggestion of this paper is to strengthened the policy of standard operational and procedure of migrant care protection at the ASEAN Society.
\end{abstract}

Keywords: UnoUnoptimized, Protection, Cooperation

\section{Introduction}

Covid-19 pandemic said to be a disruption and a crisis that has hit the world today. Various countries continue to make efforts to overcome the Covid-19 problem to date. Handling Covid-19 has also become one of the most important matters for ASEAN, even ASEAN Heads of State also continues to highlight the Covid-19 policies carried out by each Member State. ASEAN revealed that for the handling of this pandemic, it is necessary to coordinate together for recovery in it. ASEAN is committed to fighting Covid-19 with ASEAN regional cooperation, this can be seen from the holding of the High-Level Conference (Summit) on April 14, 2020, in this Summit all countries and their representatives emphasized that there is a need for coordination and also sharing of experiences so that every The approaches to policies made in dealing with this pandemic can be harmonious and the relevance in them can be measured so that they are effective for all ASEAN communities.

It has an emphasis on the implementation of Human Rights in regional cooperation between ASEAN countries. The milestones for the enforcement of world human rights are based on the 1948 Declaration of Human Rights (UDHR). In line with the realization of the 1948 DUHAM, ASEAN also declared ASEAN human rights or what is known as the 2012. Phnom Penh Declaration as the ASEAN Human Rights Declaration. 
This declaration accommodates or combines 9 (nine) points of the core instrument in the Core Instrument of Human Rights United Nations. The ASEAN Declaration in 2012 is the basis for ASEAN to be active in upholding human rights among ASEAN member countries [1]. In the internal scope of ASEAN, ten member countries agreed on several important points regarding the handling of Covid-19, namely by strengthening cooperation against Covid-19 by exchanging information, best practices, developing research, developing epidemiology, and others. The most important thing is to provide protection for ASEAN citizens, strengthen public communication and continue to work to combat stigmatization and discrimination that occurred during the pandemic crisis. In the review above, one of the important things in ASEAN Cooperation is to look at the protection of migrant workers during the Covid-19 pandemic. International Labor Organizations provide recommendations for policymakers and constituents in the world. The Covid-19 crisis has indeed shown an unprecedented significant impact, especially on the global economy, business and workers. The ILO estimates that nearly 2.2 billion workers, representing 68 percent of the global workforce, live in countries where workplace closures are required or advised, including in ASEAN member countries.

Migrant workers are considered to be a group that has a high level of vulnerability in facing the effects of the Covid-19 pandemic. The ILO states that reports document an increase in the level of discrimination against migrant workers, which can be seen through cases of food insecurity, termination of employment, worsening working conditions such as cuts in wages or unpaid wages, inadequate or inadequate living conditions, and increased restrictions. movement with forced repatriation of immigrants because they are considered carriers of the virus in the current conditions [2]. Migrant workers are often the first group to be dismissed but also the last to get access to health care and care that is in line with domestic workers. They are often excluded to the point of being forgotten from the response to a national Covid19 policy. Since the pre-pandemic era, social security and access to health were also felt to be lacking for ASEAN immigrant workers. From this explanation, the author will talk about the extent of ASEAN policies and cooperation related to labor to date, as well as possible efforts to carry out the welfare of workers with the protection of human rights of migrant workers in comprehensive ASEAN regional cooperation.

\section{Research Methods}

In explaining about Optimizing the Protection of Migrant Workers in the ASEAN Cooperation Framework, the author uses a desk study approach. The desk study/research method is a way of accessing data and information through examination and analysis of data and information using secondary data, both in the form of internal/external company documents, regulations related to RSPO, reports, statistical data, literature studies, maps, and etc.

\section{Results and Discussion}

\subsection{Human Rights in Association of Southeast Asian Nations}

Discussing the regulation of human rights stipulated in the constitutions of ASEAN countries, it also touches on ideology and international agreements in the constitutions of ASEAN countries. Basically, relations between countries have developed significantly 
through the form of cooperation. The majority of countries participate and cooperate which is manifested in various forms of international treaties such as the multilateral protection of human rights conventions and bilateral cross-country trade agreements. Many of these countries embody international treaties in the form of domestic products and can bind them nationally. There are several understandings in the process of formulating international treaties into the laws of a country. Some of the theories include monism dualism, transformation and harmonization. In the process of acceptance that is running well, it is necessary to make adjustments to the provisions and additional mechanisms of the national law. Monism tends to place international law before domestic law. Meanwhile, dualism emphasizes that each state jurisprudence has a different domain and scope of problems.

The existence of this classification is indeed necessary, this is to determine the negotiation, ratification and implementation of an international agreement which is also related to overcoming conflicts that occur to international agreements that are confused with human rights. An agreement between countries besides the existence of a bilateral, trilateral agreement is also multilateral. This becomes the basis for conflict resolution over which law occupies the higher hierarchy of the State.

Hans Kelsen and Sir Hersch Lauterpacht who are monism figures in which both believe that international law cannot and is separated from the practice of national law of a country. International law is the basis for problems that exist within the country of a country as long as it does not conflict with existing legislation [3]. Furthermore, discussing and paying attention to ASEAN countries in understanding the practice of international agreements with different backgrounds is an interesting side. The legal basis for the foreign policy that they carry out, and the related laws that regulate their relationship with international agreements, including the factors that influence it [4].

Table 1. ASEAN Societies in Their National Law.

\begin{tabular}{|c|c|}
\hline Monoism & Dualism \\
\hline Singapore & Myanmar \\
\hline Brunei Darussalam & Malaysia \\
\hline Kamboja & Indonesia \\
\cline { 2 - 2 } & Thailand \\
\cline { 2 - 2 } & Vietnam \\
\cline { 2 - 2 } & Laos \\
\cline { 2 - 2 } & Filipina \\
\hline
\end{tabular}

Sources of book: Jawahir Thontowi, 2019,

Above is a table for the division between the understandings applied by ASEAN member countries in addressing the model for implementing international agreements in an adjustment between ASEAN countries (ASEAN Society). Of the ten ASEAN member countries, all of which are members of the United Nations organization. The United Nations together with ASEAN have a high commitment to support and assist the realization of world peace, world order, and world security, by always prioritizing peaceful methods, and preventing or avoiding the use of violence in every resolution of conflicts that occur, both between friendly countries as well as conflicts between countries and their citizens.

The aims and objectives of the founding of the United Nations and ASEAN are in common so that it is not too difficult to measure in terms of compliance with international law and agreements by considering their participation in international organizations including their participation in achieving these noble aims and objectives. Thus, this is regulated in the United Nations Charter and also the ASEAN Charter. In the introduction, the author has emphasized 
that the enforcement of world human rights is based on the 1948 UDHR as the main instrument in upholding world human rights. According to the Office of the United Nations High Commissioner for Human Rights, 9 treaties are the main instruments for the fulfillment of human rights, such as :

1. International Convention on the Elimination of All Forms of Discrimination (ICERD) 1965 ;

2. International Covenant on Civil and Political Rights (ICCPR) 1966;

3. International Covenant on Economics, Social and Cultural Rights (ICESCR) 1966;

4. Convention on the Elimination of All Forms of Discrimination against Women (CEDAW) 1979;

5. Convention against Torture and Other Cruel, Inhuman or Degrading Treatment or Punishment (CAT) 1984;

6. Convention on the Rights of the Child (CRC) 1989;

7. International Convention on Protection of the Rights of All Migrant Workers and Member of Their Families (ICMRW) 1990;

8. International Convention for the Protection of All Persons from Enforced Disappearance;

9. Convention on the Rights of Persons with Disabilities (CRPD) 2006. Ratification of the main human rights instruments is mandatory for every member of the United Nations.

Treatment may be carried out with reservation or modification rights without changing the meaning following per under the interests of ratification. It can be seen from the 1969 Vienna Convention article 2 paragraph (1) letter $\mathrm{d}$ which reads;

"A unilateral statement however phrased or named, made by a State when signing, ratifying, accepting, approving or acceding to a treaty whereby it purports to exclude or to modify the legal effect of certain provisions of the treaty in their application to that State."

Concerning For, the above instruments, each country is obliged to ratify it, even though reservations are possible. The implementation of human rights in ASEAN countries is based on the 2007 ASEAN Charter mainly on article 1 point 7 which reads:

"Strengthen democracy, promote good governance and the rule of law, and promote and protect human rights and fundamental freedoms, taking into account the rights and obligations of ASEAN member states. The author expresses the view that the implementation of human rights protection is carried out on a universal concept and not based on mere regional and national principles, although the author feels that theoretically, human rights knowledge and protection are appropriate and depend on limited implications because national interests often occur ASEAN member countries" [5].

\subsection{Effectiveness in Asean Declaration Protection and Promotion of The Rights of Migrant Workers.}

As a form of implementing priority work programs related to labor mobility and social protection issues on January 13, 201, ASEAN laid the foundation for efforts to resolve the problems of migrant workers through the signing of the Declaration of Protection of the Rights of Migrant Workers. The Declaration mandates the Member States to promote justice and protection of employment, payment of wages, and adequate access to employment and housing for migrant workers. The 12th ASEAN Summit was held in Cebu, Philippines on January 13, 2007, ASEAN leaders signed the ASEAN Declaration on the Protection and Promotion of the Rights of Migrant Workers.

Obligations Of Receiving States:

1. Intensify efforts to protect the fundamental human rights, promote the welfare and uphold human dignity of migrant workers; 
2. Work towards the achievement of harmony and tolerance between receiving states and migrant workers;

3. Facilitate access to resources and remedies through information, training and education, access to justice, and social welfare services as appropriate and in accordance with the legislation of the receiving state, provided that they fulfill the requirements under applicable laws, regulations and policies of the said state, bilateral agreements and multilateral treaties;

4. Promote fair and appropriate employment protection, payment of wages, and adequat access to decent working and living conditions for migrant workers;

5. Provide migrant workers, who maybe victims of discrimination, abuse, exploitation, violence, with adequate access to the legal and judicial system of the receiving states; and

6. Facilitate the exercise of consular functions to consular or diplomatic authorities of states of origin when a migrant worker is arrested or committed to prison or custody or detained in any other manner, under the laws and regulations of the receiving state and in accordance with the Vienna Convention on Consular Relations.

Obligations Of Receiving States :

1. Enhance measures related to the promotion and protection of the rights of migrant workers;

2. Ensure access to employment and livelihood opportunities for their citizens as sustainable alternatives to migration of workers;

3. Set up policies and procedures to facilitate aspects of migration of workers, including recruitment, preparation for deployment overseas and protection of the migrant workers when abroad as well as repatriation and reintegration to the countries of origin; and

4. Establish and promote legal practices to regulate recruitment of migrant workers and adopt mechanisms to eliminate recruitment malpractices through legal and valid contracts, regulation and accreditation of recruitment agencies and employers, and blacklisting of negligent/unlawful.

\subsection{ASEAN Declaration Protection and Promotion of The Rights of Migrant Workers as Legal Instruments in Realizing Human Rights Protection for Migrant Workers ASEAN Society (Seeing Indonesia as Part of the ASEAN Society) During of Pandemic Covid-19.}

The Association of Southeast Asian Nations (ASEAN) as a regional institution in Southeast Asia has until now been maximally established. This can also be seen since the Covid-19 pandemic emerged in early January 2020, no ASEAN member country has escaped the Covid-19 case. The Covid-19 pandemic has an impact that refers to various countries in Southeast Asia in a situation of worry and continues to strive so that the economy, welfare, and access to health can continue. On April 14, 2020, ASEAN held a High-Level Conference related to Covid-19. This good step was taken for ASEAN regional cooperation, which is expected to be a solution to overcome the impact of Covid-19. The author agrees with Migrant Care to also appreciate this step and give the view that this declaration is very normative and has not answered crucial issues regarding the Covid-19 outbreak and its impact on vulnerable communities in the ASEAN region, especially for migrant workers.

The author raises point number 9 in the Declaration of the Special ASEAN Summit on Coronavirus Disease 2019 (COVID-19), in this case, explains that indeed the development 
efforts taken by member countries will be supported, the author is of the view that this is only normative and general because it is not specific protection of human rights for migrant workers. The Declaration of the Special ASEAN Summit on Coronavirus Disease 2019 (COVID-19) on April 142020 further elaborates on the exchange of information and mentions strengthening public health cooperation measures to limit the pandemic and protect people who are also the main things.

In line with the introduction, the author emphasizes that migrant workers are one of the most important. Striving for health but by ignoring non-health aspects in handling the Covid19 crisis in the Southeast Asia region raises speculation that ASEAN in dealing with Covid-19 amid the high status of Human Rights is fairly slow. Covid-19 is a pandemic that crosses national borders, so cooperation betweenn countries especially within a regional framework is an absolute thing, and it is also carried out with a comprehensive approach. However, this statement will only become rhetoric if ASEAN divides its interests in the context of protecting migrant workers. Before going further, the author would like to address the problems that often occur to migrant workers in various countries. For an example, see the table of data below, released on 2013.

Table.2. The problem of migrant workers in various countries in 2013.

\begin{tabular}{|c|l|l|}
\hline Number. & \multicolumn{1}{|c|}{ Problems } & Amount/Total \\
\hline 1 & Mortality & 1.249 \\
\hline 2 & Death Penalty & 256 \\
\hline 3 & Overstayers & 197.361 \\
\hline 4 & Unpaid of Salaries & 15.208 \\
\hline 5 & Workload & 6.310 \\
\hline 6 & Sexual violence & 4.302 \\
\hline 7 & Kekerasan fisik & 3.245 \\
\hline 8 & Lost Contact & 567 \\
\hline 9 & Deportation & 8.514 \\
\hline 10 & Sickness & 987 \\
\hline 11 & Work Termination & 1.430 \\
\hline 12 & List of Permanent Voters Abroad & 157.602 \\
\hline 13 & Etc & $\mathbf{3 9 8 . 2 7 0}$ \\
\hline & \multicolumn{2}{|c}{ Total } \\
\hline
\end{tabular}

Sources : Migrant Care Indonesia 2013.

The data above is a benchmark for things that are often a problem for migrant employees. As reported by the media Solidaritas Perempuan Organization Indonesia, the survey conducted by HRWG together with SDBMI and JBM in the period 21-30 April 2020, shows that there are various problems faced by Indonesian migrant workers in several some countries, including among ASEAN member countries [7].

Developed by the author based on the Indonesian Women's Organization Solidartias media which states that there is media analysis data conducted by the Migrant Workers Network of Indonesia (Jaringan Buruh Migran Indonesia) showing that there has been a very large increase in cases, namely as much as $61 \%$ when compared to 2019 , especially cases of repatriation by deportation and repatriation Indonesian migrant workers, especially Indonesian migrant workers who do not have passport documents.

Also besides, there are cases of detention of Indonesian migrant workers in conditions that cause trauma to Indonesian migrant workers. During the Covid-19 pandemic, of the 35 
survey respondents that were being carried out by the Migrant Workers Network, for example, and temporarily showing the conditions of Indonesian Migrant Workers during the pandemic were more vulnerable to worse work situations including a heavier workload, there were cuts in wages, no holidays and it was difficult to get together, especially to organize.

The Indonesian Migrant Workers Union (Serikat Buruh Migran Indonesia) also noted in the Catahu report that in 2020 there was an increase in cases compared to 2019 with a variety of cases experienced by Indonesian migrant workers in the form of physical violence, abuse, sexual harassment, violations of work contracts, economic exploitation, human trafficking, and disappearances. lives by force because of the criminalization experienced. Data Solidaritas Perempuan further shows the occurrence of layered violence experienced by women migrant workers in Indonesia. Of the 63 reported cases, there were 188 types/forms of cases experienced.

The handling of cases carried out also shows that trafficking victims in general also experience various other forms of violence, such as physical violence and document detention. The Covid-19 pandemic that occurred and also women migrant workers increasingly vulnerable and had limited mobility, both in accessing their daily needs and legal assistance and assistance when experiencing cases. Besides of detention exceeded the time limit at the Temporary Detention Center in Tawau, Sabah, which is commonly known as Rumah Merah and is known among workers as a place of torture as much as $10 \%$. This high figure is closely related to ASEAN's policies on migrant workers in ASEAN member countries and the delay in deportation due to the Indonesian government's unpreparedness to facilitate the return of Indonesian migrant workers in the situation of the Covid-19 pandemic [8].

Developed by the author based on the BBCNews Indonesia media, the story of migrant workers in Indonesia who said Indonesian migrant workers experienced work rights violations during the coronavirus outbreak, ranging from layoffs (layoffs), unpaid salaries, lack of accessibility for migrant workers to check their health. BBC News Indonesia revealed that the results of the HRWG survey together with the Indonesian Migrant Workers Union and the Migrant Workers Network for the period of 21-30 April 2020 showed a variety of problems faced by Indonesian migrant workers in several countries. The survey showed that around $54 \%$ of migrant workers in Indonesia who work as factory and construction workers, such as in Malaysia, said didn't receive a salary, while $95 \%$ of Indonesian migrant workers in Singapore, although still working and getting a salary, receive multiple workloads, restrictions on mobilization, deprivation of rights. holidays, depression and not getting overtime pay.

From the description of the survey above, the author states that the conditions of Indonesian migrant workers before the pandemic and during the pandemic were still in a concerning situation. The rights of migrant workers in the constitutions of ASEAN countries are deprived. The author also emphasizes that the main point of the Declaration on Protection and Promotion of the Rights of Migrant Workers in Cebu is aimed at achieving a joint action in enhancing the protection and promotion of the rights of migrant workers in ASEAN.

There are three main principles set out in this declaration [9]:

1. Optimization the benefits of migrant workers without harming the dignity of every migrant worker.

2. Solution of problems that cause migrant workers to change their legal status to become illegal.

3. Protection of the rights and dignity of migrant workers and their entire families. 
General Principles of Declatarion at Cebu,Phillipines:

1. Both the receiving states and sending states shall strengthen thepolitical,economic and social pillars of the ASEAN Community by promoting the full potential and dignity of migrant workers in a climate of freedom, equity, and stability in accordance with the laws, regulations, and policies of respective ASEAN Member Countries;

2. The receiving states and the sending states shall, for humanitarian reasons, closely cooperate to resolve the cases of migrant workers who, through no fault of their own, have subsequently become undocumented;

3. The receiving states and the sending states shall take into account the fundamental rights and dignity of migrant workers and family members already residing with them without undermining the application by the receiving states of their laws, regulations and policies; and

4. Nothing in the present Declaration shall be interpreted as implying the regularisation of the situation of migrant workers who are undocumente.

\subsection{The commitment of ASEAN countries can also be seen in the ASEAN Social-Cultural Community (ASCC) which has integrated the issue of protection for migrant workers.}

One of the elements contained in the ASCC 2025's Blueprint [9]

"Enhance regional initiatives in accordance with the ASEAN Declaration on the Protection and Promotion of the Rights of Migrant Workers to improve the protection and promotion of the rights of workers and migrant workers."

In 2011 there were 4 meetings since the first meeting in 2008 in Singapore. September 15-16, 2008, the ASEAN Committee on the ASEAN Declaration on The Protections of the Rights of Migrant Workers (ACMW) was formed based on the declaration of the ASEAN Foreign Ministers with three strategic objectives.

1. Thrust 1: Step up protection and promotion of the rights of migrant workers against exploitation and mistreatment.

2. Thrust 2: Strengthen protection and promotion of the rights of migrant workers by enhancing labour migration governance in ASEAN Countries.

3. Thrust 3: Regional cooperation to fight human trafficking in ASEAN [10].

ACMW had been appointed as the executor of the mandate of the Cebu Declaration, and in which ASEAN member sending countries are divided into two camps that have an element of interest, namely countries of sending and receiving countries of migrant workers. The sending party consists of six countries, namely: 1) Indonesia, 2) Philippines, 3) Cambodia, 4) Laos, 5) Vietnam and 6) Myanmar. Meanwhile, the receiving countries consisted of 1) Malaysia, 2) Singapore, 3) Brunei Darussalam, and 4) Thailand.

Reviewing what was presented by the author from the previous explanation that in the Declaration of Cebu, it has been explained that sending countries and receiving countries have the same responsibility in enforcing the protection of migrant workers with an objective sense of mutual interest without any egocentric elements between countries. Furthermore, the author view that the lack of protection of human rights for migrant workers affects a very important aspect. This gives workers who are hampered due to the lack of access to health and appropriate wages or basic rights for migrant workers that affect economic figures and the quality of life for humans by observing the human development index released by the United Nations Development Program, in line with the World Bank's statement. estimates a decrease in remittances from the workforce in 2020. This decrease will also trigger an increase in the 
poverty rate and a decrease in the quality of human life in line with the expression in the United Nations Development Program [11]

Table 3. The Benchmarks for Migrant Workers.

\begin{tabular}{|c|c|c|}
\hline Number & UN Convention 1990 & $\begin{array}{l}\text { ASEAN Declaration on the Protection and } \\
\text { Promotion of the Rights of Migrant Worker }\end{array}$ \\
\hline 1. & $\begin{array}{l}\text { Protected from all forms acts } \\
\text { of torture or treatment or cruel } \\
\text { punishment, no humane and } \\
\text { condescending dignity. }\end{array}$ & $\begin{array}{l}\text { The right to be protected and upheld high human } \\
\text { rights and dignity as a migrant worker in the } \\
\text { country where he works. }\end{array}$ \\
\hline 2. & $\begin{array}{l}\text { Protected from the practice of } \\
\text { slavery. }\end{array}$ & $\begin{array}{l}\text { Protected from exploitation practices and } \\
\text { mistreatment. }\end{array}$ \\
\hline 3. & $\begin{array}{l}\text { Protected from the practice of } \\
\text { forced labor or compulsory } \\
\text { labor. }\end{array}$ & Protected against human trafficking. \\
\hline 4. & $\begin{array}{l}\text { Legal protection of right to } \\
\text { life. }\end{array}$ & Advance of the rights. \\
\hline 5. & $\begin{array}{l}\text { Right to enter and stay on } \\
\text { country of origin at all times. }\end{array}$ & $\begin{array}{l}\text { Entitled to resource access of facilities power and } \\
\text { medicine through information, training and } \\
\text { education. }\end{array}$ \\
\hline 6. & $\begin{array}{l}\text { Right to freedom of thought, } \\
\text { belief, and religion. }\end{array}$ & $\begin{array}{l}\text { Right to access to justice and social welfare } \\
\text { services. }\end{array}$ \\
\hline 7. & $\begin{array}{l}\text { Have the right to } \\
\text { communicate opinion. }\end{array}$ & $\begin{array}{l}\text { Entitled to adequate access against the legal and } \\
\text { judicial systems recipient countries for the migrant } \\
\text { workers, that maybe a victim of discrimination, } \\
\text { harassment, exploitation, violence. }\end{array}$ \\
\hline 8. & $\begin{array}{l}\text { a single migrant worker and } \\
\text { family members who can } \\
\text { arbitrarily or arbitrarily } \\
\text { illegitimate meddled with } \\
\text { problems personal, family, } \\
\text { home or correspondence or } \\
\text { other communications, or } \\
\text { otherwise } \\
\text { legitimately attacked by honor } \\
\text { and name }\end{array}$ & $\begin{array}{l}\text { Entitled to facilities the exercise of consular } \\
\text { functions of the consular or diplomatic authorities } \\
\text { country of origin when a worker migrant are } \\
\text { arrested or entered }\end{array}$ \\
\hline 9 & $\begin{array}{l}\text { It's good. And deserve legal } \\
\text { protection for these acts. }\end{array}$ & $\begin{array}{l}\text { Into prison or custody or being detained in another } \\
\text { way, based on the law and receiving country } \\
\text { regulations and in accordance with the Vienna } \\
\text { Convention on Consular Relations. }\end{array}$ \\
\hline 10. & $\begin{array}{l}\text { Have right to own good } \\
\text { property owned alone or with } \\
\text { people or other. }\end{array}$ & $\begin{array}{l}\text { Have right to access to justice and social welfare } \\
\text { services as appropriate under the laws of the host } \\
\text { country, provided they meet the requirements based } \\
\text { on applicable law, state regulations and policies } \\
\text { these, bilateral agreements and multilateral } \\
\text { agreement. }\end{array}$ \\
\hline 11. & $\begin{array}{l}\text { Migrant workers who do } \\
\text { a criminal act is entitled to } \\
\text { receive fair trial before the } \\
\text { judge or other officials given } \\
\text { authority by law to run with } \\
\text { the judiciary. }\end{array}$ & \\
\hline
\end{tabular}




\begin{tabular}{|c|l|l|}
\hline 12 & $\begin{array}{l}\text { Entitled to protection } \\
\text { and assistance of consular } \\
\text { officials or diplomatic status } \\
\text { from their home/country. }\end{array}$ & \\
\hline & $\begin{array}{l}\text { Have to get that treatment no } \\
\text { less profitable than applied to } \\
\text { citizens country of work in } \\
\text { terms of payroll and working } \\
\text { conditions others are overtime } \\
\text { pay, hours work, weekly rest, } \\
\text { holidays with salary, safety, } \\
\text { health, termination of } \\
\text { employment, and whatever } \\
\text { conditions are according to } \\
\text { national law and } \\
\text { practice covered in this term. }\end{array}$ & \\
\hline
\end{tabular}

Sources: Developed by Authors from Mr.Muhammad Reynaldo Humam Akbar's Primary of Data on 2014 [11].

In the internal development of ASEAN itself, the ten member countries agreed on several important points regarding the handling of Covid-19 by exchanging information, best practices, developing research, developing epidemiology, etc. As well as protecting ASEAN nationals amid the pandemic, public communication and efforts to change stigmatization and discrimination committed to taking collective action and coordinated policies to mitigate economic and social impacts, assisting multi-stakeholder and multi-stakeholder approaches. sectoral, assigning ASEAN economic ministers to ensure supply chain connectivity so that trade can continue, as well as supporting the reallocation of the ASEAN Trust Fund to tackle the Covid-19 virus pandemic.

Also, the leaders of ASEAN countries decided to form a regional fund to create the Covid-19 pandemic. The regional forces are important in the medical region and important in the ASEAN region. This fund comes from the reallocation of available financial funds and is assisted by a commitment to refrain from spending less important funds amid the pandemic (ASEAN Declaration held in June 2020) [12].

\section{Conclusion}

ASEAN as a regional institution in Southeast Asia is trying to fight Covid-19, which until now has been faced together. All ASEAN member countries expressed concern by taking action by proposing regional cooperation in efforts to overcome the Covid-19 pandemic. ASEAN has held a Special Summit on Covid-19 and produced a declaration entitled "Declaration of the Special ASEAN Summit on Coronavirus Disease 2019". The author reveals that from this declaration, nursing does not answer crucial issues, especially for migrant workers.

The survey showed that around 54\% of migrant workers in Indonesia who work as factory and construction workers, such as in Malaysia, said didn't receive a salary, while $95 \%$ of Indonesian migrant workers in Singapore, although still working and getting a salary, receive multiple workloads, restrictions on mobilization, deprivation of rights. holidays, depression and not getting overtime paid. 
Lack of human rights protections for ASEAN migrant workers, where ASEAN is still quite slow in handling Covid-19. The declaration that occurred in April 2020 to June 2020 is still not maximal in paying attention to non-health aspects that also influence each other, such as protecting human rights of migrant workers related to wages and providing access to health amid during the Covid-19's emergency. The emergence of policies in various countries that have resulted in cases of condemnation of human rights such as the one in Malaysia and the spike in cases of covid-19 in migrant workers' settlements in Singapore and the authors compare this incident by showing the strength of the ASEAN Declaration on the Protection and Promotion of the Rights of Migrant Workers to examining cases of Indonesian migrant workers in ASEAN recipient countries.

The World Bank and UNDP stated that the handling of Covid-19 is still weak which will have an impact on the workforce, increase the poverty rate and reduce the quality of life in the human development index Covid-19 and produced a declaration entitled "Declaration of the Special ASEAN Summit on Coronavirus Disease 2019". The author reveals that from this declaration, nursing does not answer crucial issues, especially for migrant workers.

\section{Suggestions}

1. The author suggests that ASEAN can take steps by embracing migrant worker organizations or associations in cooperation through the Ministries or Departments of Foreign Affairs of ASEAN member countries in the context of advocacy and protection of human rights for migrant workers who have been affected by the pandemic.

2. The authors suggest that the ASEAN Community can establish a special community to help protect the implementation of things and monitor migrant workers within ASEAN member countries, and this also supports the creation of a formula for the protection of workers' rights through the ACMW by following and accordance with the 1990 UN convention

\section{References}

[1] Jawahir Thontowi, 2019, Perjanjian International Dan Hak Asasi Manusia Dalam Konstitusi Negara-Negara Asean (International Treaties and Human Rights in The Constitution of Asean Countries), Yogyakarta -Indonesia, Uii Press Yogyakarta.

[2] Adelia Maretha, M.Irfan, Pengaruh Masyarakat Ekonomi Asean Terhadap Kondisi Ekonomi Asean Terhadap Kondisi Dan Mobilitas Tenaga Kerja Asean, Journal Ilmiah Frequency Of International Relations, Vol 2(2) 31-61 ,February 2021 Faculty Of Social And Politics, Sriwijaya University.

[3] Asean. Declaration On Protection and Promotion of The Rights of Migrant Workers (Online), Asean Declaration on The Protection and Promotion of The Rights of Migrant Workers - Asean | One Vision One Identity One Community, (13 March 2021).

[4] Dw (Deutsche Welle) In Indonesia Media, Asean Lupa Soal Perlindungan Pekerja Migran Dalam Protokol Covid-19? | Kolom: Bersama Berdialog Untuk Mencapai Pemahaman | Dw | 13.06.2020 (Online On 15 March 2021).

[5] Indonesia Institute of Sciences (Lipi) : Asean in Regional Cooperation Challenges, Https://Ssl.Microsofttranslator.Com/Bv.Aspx?Ref=Tans\&From=\&To=Id\&A=Http\%3a\%2f\%2fpsd r.Lipi.Go.Id\%2 Fnews-And-Events\%2fopinions\%2ftantangan-Kerja-Sama-RegionalAsean-Dalam- Melawan-Covid-19. Html (Online On 16 March 2021).

[6] Ilo Policy Brief, Aril 2020 (Online), Protection of Migrant Workers During a Pandemic Covid-19: Recommendations for Policy Makers And, Https://Www.Ilo.Org/Wcmsp5/Groups/Public/- Asia/--Ro-Bangkok/---Ilo-Jakarta/Documents/Publication/Wcms_745598.Pdf, (Online On 18 March 2021). 
[7] Medianeliti, Muhammad Reynaldo, Implementation of Asean Declaration Protection and Promotion of The Rights of Migrant Workers in Make a Fair and Appropriate Working Condition Indonesian Migrant

[8] Workers' 35161-Id-Pelaksanaan-Asean-Declaration-Protection-And-Promotion-Of-The- RightsOf-Migrant.Pdf (Neliti.Com), (Online On 19 March 2021).

[9] Asean ,Asean Charter 1967. (Online, Terjemahan Piagam Asean_Satu

[10] Naskah Final_6 Feb 2008 Deplu.Doc, 20 March 2021).

[11] Asean Socio-Cultural Community Blueprint 2025, Ascc-Blueprint-2025.Pdf

[12] (Asean.Org), On 20 March 2021.

[13] Solidaritas Perempuan.Org Media: Portrait of Policies and Human Rights Violations Against Indonesian Migrant Workers

Throughout 2020, (Online),

Http://Www.Solidaritasperempuan.Org/Potret-Kebijakan-Dan-Pelanggaran-Ham-TerhadapPekerja- Migran-Indonesia-Sepanjang-2020/,

On 20 March 2021.

[14] Raja Eben Lumban Rau: The Stories of Indonesian Migrant Workers in The Midst of The Corona Virus Outbreak: From Not Being Paid, Being Laid Off, Finding It Difficult to Buy a Toothbrush to Sleeping on A Cupboard (Online),

[15] Https://Ssl.Microsofttranslator.Com/Bv.Aspx?Ref=Tans\&From=\&To=Id\&A=Https\%3a\%2f\%2fw ww.B Bc. Com\%2findonesia\%2findonesia-52607651 On 20 March 2021 